belong also the remains from the Ohesaare Stage $\left(K_{4}\right)$ identified before as Andreolepis sp. [ [4].

As the recent study shows, a rich thelodont assemblage, earlier known from the Ohesaare Stage $\left(\mathrm{K}_{4}\right)$ only, occurs already in the Paadla Stage, and thus the difference between the Upper Ludlovian and Downtonian vertebrate faunas is not so great as it was suggested previously $\left[{ }^{1,7}\right]$ on a more limited material. Nearly all the same groups are present in both of them. As compared to these faunas the Wenlockian and Lower Ludlovian vertebrate fauna is poorer.

\title{
REFERENCES
}

1. Gross W. 1950. Die paläontologische und stratigraphische Bedeutung der Wirbeltierfaunen des Old Reds und der marinen altpaläozoischen Schichten. Abh. Deutsch. Akad. Wiss. Berlin, Math. - naturwiss. K1., Jg. 1949.

2. Об руче в Д. В. 1958. К биостратиграфии ихтиофаун нижнего и среднего палеозоя. С.СС. Сов. геол., 11.

3. Gros s W. 1967. Uber Thelodontier-Schuppen. Palaentographica, 127 A.

4. Mark-Kurik E. 1969. Distribution of vertebrates in the Silurian of Estonia. Lethaia, 2.

5. К альо Д. Л. (Ред.). Силур Эстонии. Таллин (в печати).

6. Gros s W. 1968. Fragliche Actinopterygier-Schuppen aus dem Silur Gotlands. Lethaia, 1.

7. Obruchev D., Karatajütè-Ta lima a V. 1967. Vertebrate faunas and correlation of the Ludlovian - Lower Devonian in eastern Europe. J. Linn: Soc. (Zool.), 47, 311.

Academy of Sciences of the Estonian SSR, Institute of Geology

EESTI NSV TEADUSTE AKADEEMIA TOIMETISED. 19. KÖIDE KEEMIA * GEOLOOGIA. 1970, Nir. 2

ИЗВЕСТИЯ АКАДЕМИИ НАУК ЭСТОНСКОН ССР. ТОМ 19 ХИМИЯ * ГЕОЛОГИЯ. 1970, № 2

О. $Э$ НЕНН, Э. СНМОН

\section{ГАЗОХРОМАТОГРАФИЧЕСКОЕ ОПРЕДЕЛЕНИЕ СОДЕРЖАНИЯ СПИРТОВ В ВИНАХ}

\author{
O. EISEN, E. SIMON. VEINIDE ALKOHOLISISALDUSE MÄARAMINE \\ GAASIKROMATOGRAAFIA ABIL \\ O. EISEN, E. SIMON. BESTIMMUNG DES ALKOHOLGEHALTS IM WEIN MITTELS \\ GASCHROMATOGRAPHIE
}

Для контроля пищевых продуктов в последнее время широко применяется газохроматографический метод. Ряд работ как в Советском Союзе, так и за рубежом посвящен газохроматографическому определению качества алкогольных напитков. В настоящей работе впервые приво. дятся результаты определения качественного и количественного состава спиртов в вннах, изготовляемых в Әстонской ССР. Для сравнения приводятся данные по одному сорту плодово-ягодного вина и коньяка, изготовляемых за пределами Эстонской ССР.

Использовались хроматографы Хром-1 и Хром-2 с капиллярной колонкой длиной 40 м, диаметром 0,25 мм из нержавеющей стали с триэтиленгликолдибутиратом и насадочными колонками длиной $1,7 \stackrel{\mu}{\text { и }} 6 \boldsymbol{M}$ с наполнителем из $20 \%$ полиэтиленгликоля 4000 на хромосорбе W $(60$ - 
Содержание спиртов в винах и коньяке, \%

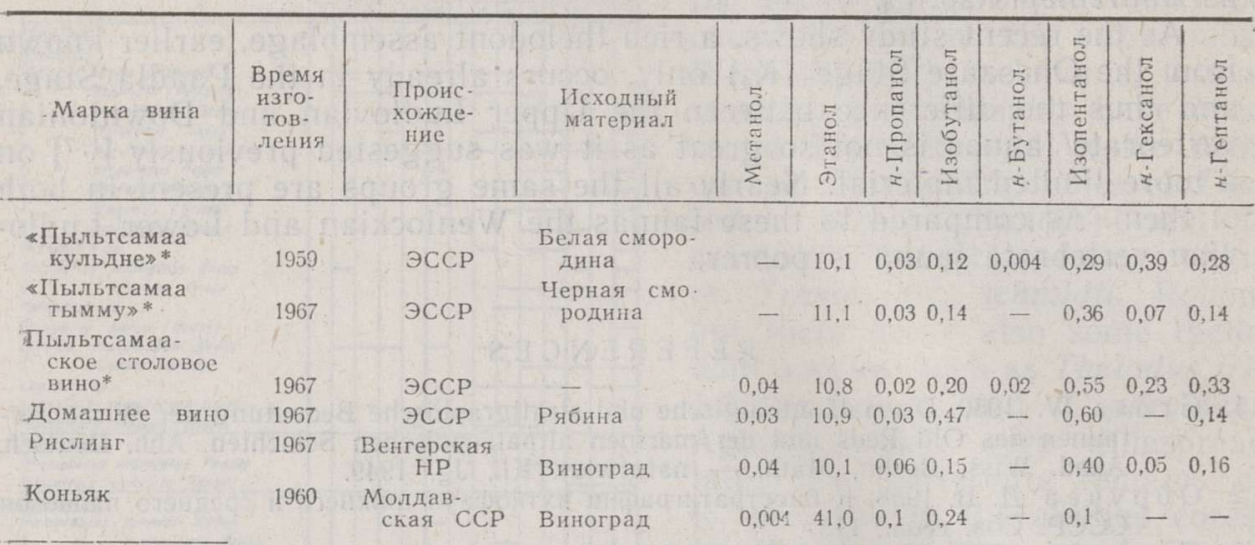

* Изтотовле:с на сельскохозяйственіном комбинате ЭРСПО Пыльтсамаа

80 меш). Пики спиртов были идентифицированы с помощью эталонных веществ. 500 мл вина экстрагировали 4-5 раз диэтиловым эфиром $\left(100\right.$ мл). Полученные экстракты объединяли и из них отгоняли при $35^{\circ} \mathrm{C}$ эфир без потери спиртов. Получали 50-55 мл экстракта. При экстрагировании из 250 мл коньяка получали 110 мл экстракта. Экстракты анализировали газохроматографически. Результаты анализа приведены в таблице.

Выяснилось, что по содержанию этанола исследованные вина мало отличаются друг от друга. Из других нормальных спиртов идентифицированы метанол, н-пропанол, н-бутанол, н-гексанол и н-гептанол. Низким содержанием отличаются метанол, н-пропанол и н-бутанол. Изобутанол, изопентанол и высшие спирты обнаружены в довольно больших количествах. Наибольшим содєржанием изопентанола характеризуется домашнее вино и Рислинг. По сравнению с винамғ анализируемый коньяк помимо этанола содержит очень мало других спиртов.

Ннститут химии

Академии наук Эстонікой ССР

Поступила в редакцию 9/XII 1969

\section{EESTI NSV TEADUSTE AKADEEMIA TOIMETISED. 19. KOIDE} KEEMIA * GEOLOOGIA. 1970. Nr. 2

ИЗВЕСТИЯ АҚАДЕМИИ НАУК ЭСТОНСКОЙ ССР. ТОМ 19 ХИМИЯ * ГЕОЛОГИЯ. 1970, № 2

A. ИВАНОВ, О. ЭИЗЕН

\section{К ВОПРОСУ О КОЛИЧЕСТВЕННОИ ИНТЕРПРЕТАЦИИ ХРОМАТОГРАММ}

A. IVANOV, O. EISEN. KROMATOGRAMMIDE KVANTITATIIVSEST INTERPRETEERIMISEST

A. IWANOW, O. EISEN. UBER DIE QUANTITATIVE INTERPRETATION DER CHROMATOGRAMME

Количественное определение содержания компонентов в сложных смесях на основании газохроматографического анализа производится обычно путем измерения площадей ликов $S_{i}$ на хроматограмме. Известны также расчеты, основанные на измерении величин пропорциональ- 